\title{
研究論文
}

\section{サトウキビ栽培における作業可能日数 拡大のための圑場排水性改善技術}

深見公一郎*・杉本光穂 ${ }^{* *} \cdot$ 新里良章*** ・赤地 徹***

*(独)農業・食品産業技術総合研究機構中央農業総合研究センター

**(独)農業・食品産業技術総合研究機構九州沖縄農業研究センター

***沖縄県農業研究センター

A Field Drainage Improvement Technique for Increasing the Working Period in Sugarcane Fields

\author{
Koichiro Fukami*, Mitsuho Sugimoto**, Yoshiaki Shinzato*** and Tohru Akachi*** \\ * National Agricultural Research Center NARO \\ ** National Agricultural Research Center for Kyushu Okinawa Region NARO \\ *** Okinawa Prefectural Agricultural Research Center
}

\section{1. 緒言}

沖縄本島中南部地域に分布するジャーガル (Jahgaru soil）は，粘土を $50 \%$ 以上含んだ重粘土で あり, 透水係数が $10^{-8} \sim 10^{-6} \mathrm{~cm} / \mathrm{s}$ 之低く, 排水性 が悪い（宮城調勝 1976).さらに土壌含水比が 25 から 35\%d.b.に増加すると一軸圧縮強度, せ九断 抵抗およびコーン指数が 2 分の 1 程度に減少し, 逆に付着力は 2 倍程度に増加する (泉ら 1981). こ のような土壤物理性を有するため, ジャーガル國 場では降雨後数日間は機械作業が行えないことが 多い，特に機械化一貫体系が確立しているサトウ キビ栽培においては, 圃場の排水不良が適期作業 を妨げる要因になり, サトゥキビの発芽不良や糖 度低下に直結する (大城・浜川 1980). 以上のこと から, 固場排水性の改善はジャーガル地域のサト ウキビ栽培における喫緊の課題である. 著者らは, プラウ（plow）の耕起とサブソイラ (subsoiler) の心土破砕の両方の機能を持ち，プラウの代替機

平成 21 年 2 月 9 日受付

平成 21 年 5 月 9 日受理

Corresponding author

深見公一郎 Koichiro FuKaml

テ514-2392 三重県津市安濃町草生 360

360 Kusawa, Ano, Tsu, Mie, 514-2392, Japan

E-mail : kofukami@affrc.go.jp
として久米島や宮古島のサトゥキビ農家を中心に 普及が拡大している作業機（スガノ農機(株) : プ ラソイラ, 以後, 排土型心土破砕機（排土型）之 呼称する）を基軸とした圃場排水性改善技術の開 発を平成 $15 \sim 19$ 年度にかけて行ってきた。 その 結果, 区画 $12 \times 41 \mathrm{~m}$ のジャーガル戋場に打いて 排土型を用いて, 深さ $45 \mathrm{~cm}$, 処理間隔 $130 \mathrm{~cm}$ で 格子状に心土破砕を行った後, 油圧ショベルを用 いて幅 $50 \mathrm{~cm}$, 深さ $50 \mathrm{~cm}$ の額縁明渠を施工し, 自動排水ポンプを用いて明渠水位を $15 \sim 25 \mathrm{~cm}$ に調整すると圃場の排水性が大幅に改善され，土

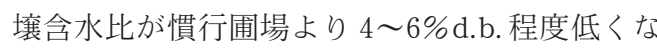
ることなどを明らかにした（深見ら 2006c)。しか し, この方法は, ポンプの整備および額縁明渠の 施工に多くの時間と経費を要する問題があった. そこで, 本研究ではポンプと額縁明渠を必要とし ない, より簡易な排水性改善技術として, 心土破 砕部からの水を圃場の一力所に集め, それを自然 流下で排水する方法 (以後, 「排水ピット方式」と 呼称する）を開発し, その排水性改善効果を, 圃 場実験より得られた機械の作業限界水分との関係 に基づいて評価した。 


\section{2. 研究方法}

1）排水性改善効果実証試験

（1）排水ピット方式の施工方法

図 1 に施工法の概要を示す。本技術は心土破砕 により形成された孔からの排水を圃場端に設けた 排水ピットに収集するシステムである。心土破砕 には排土型（プラソイラ：3PY3K ; 排土板幅 : 7.5 $\mathrm{cm}$; ナイフ本数 : 2) を用いた。作業深は $50 \mathrm{~cm}$, ナイフ間隔はサトゥキビの作付け条間の $130 \mathrm{~cm}$ とし，夏植および春植の新植時には格子状，株出 時には株を傷つけない上うに条間に沿ってのみ心 土破砕を施工した。排水ピットの施工には油圧 ショベルを用い，心土破砕の作業深さに合わせて 深さ $50 \mathrm{~cm}$, 縦横の幅は $260 \mathrm{~cm}$ （ナイフ間隔の 2 倍）とした。また排水ピットには，ピット内の透 水性を確保し有孔管への土砂流入を防止するため に，疎水材として浄水ケーキ（浄水場で濾過後の 有機物等を脱水・固結させた物）を充填するが， その際にも油圧ショベルを利用した，疎水材は一 度有孔管の設置位置まで充填し，有孔管と塩ビ管 を設置後，再充填を行った，有孔管等の設置深さ は, 深見ら (深見ら 2006c) の報告に基づいて地表 面加ら $30 \mathrm{~cm}$ に設定した。なお，機械作業等によ る有孔管等の破損を防止するために，排水ピット の設置位置には目印をつけた。

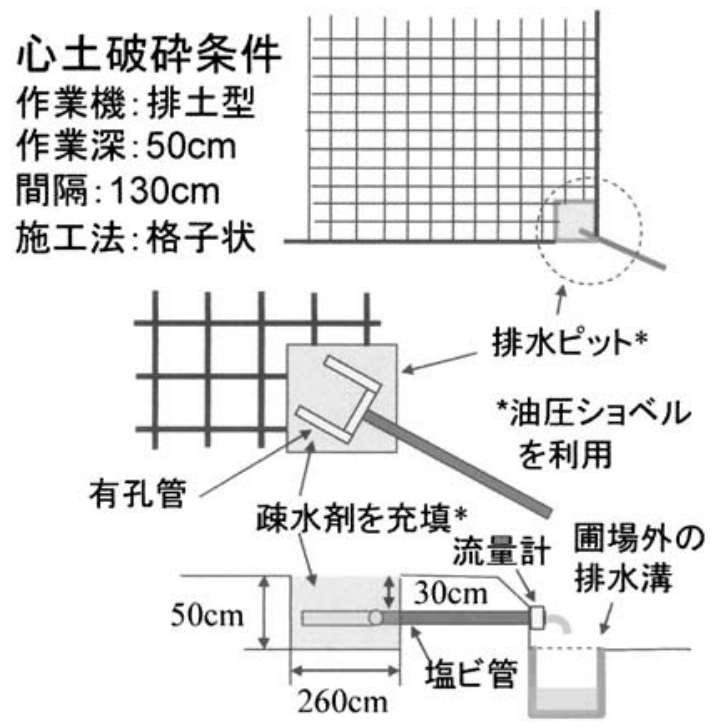

図 1 排水ピット方式の概要
（2）人工降雨試験による排水ピット方式の排水性 改善効果の検証

供試圃場は沖縄県農業研究センター（糸満市） 内のジャーガル圃場とし，試験区は排水ピット方 式を導入した改善区（5a:25×20 m) とプラウ耕 起のみの慣行区（5a : $25 \times 20 \mathrm{~m} ）$ を設置した。図 2 に試験区の概要を示す。人工降雨試験は，潅水 チューブを用いて $16 \mathrm{~mm} / \mathrm{h}$ で水を $6 \mathrm{~h}$ 投入し， 潅水後 6 日までの土壤水分の変化について解析を 行った．排水ピットからの排水量は，塩ビ管の先 に取り付けた羽根車式流量計で測定した。土壌含 水比は TDR 水分センサ（デカゴン社：ECHO-10) の出力值と実測した土畩含水比 (\%d.b.) の関係 式 (図 3) に基づいて測定した。 センサは 1 区につ

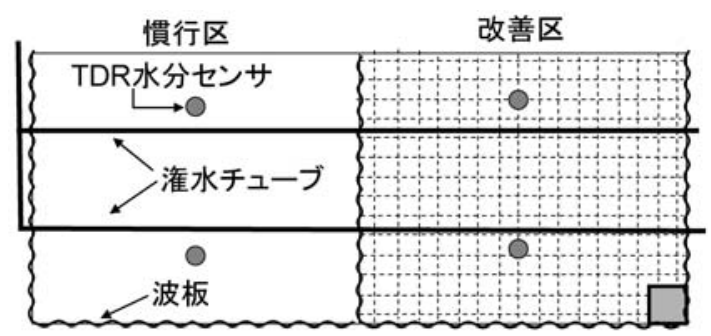

設置場所: 沖縄県農業研究センター(糸満市)内 ジャーガル戋場

試験区 : 改善区(排土型十ロータリ)

慣行区(プラウーロータリ)

面積: 縦 $20 \mathrm{~m} \times$ 横 $25 \mathrm{~m}$ (5a/区)

人工降雨試験実施日: 2006/9/21

潅水条件: $16 \mathrm{~mm} / \mathrm{h}$,合計 $96 \mathrm{~mm}(6 \mathrm{~h})$

TDR水分センサ: 深さ0 $10 \mathrm{~cm}$,2力所設置

図 2 排水試験区の概要

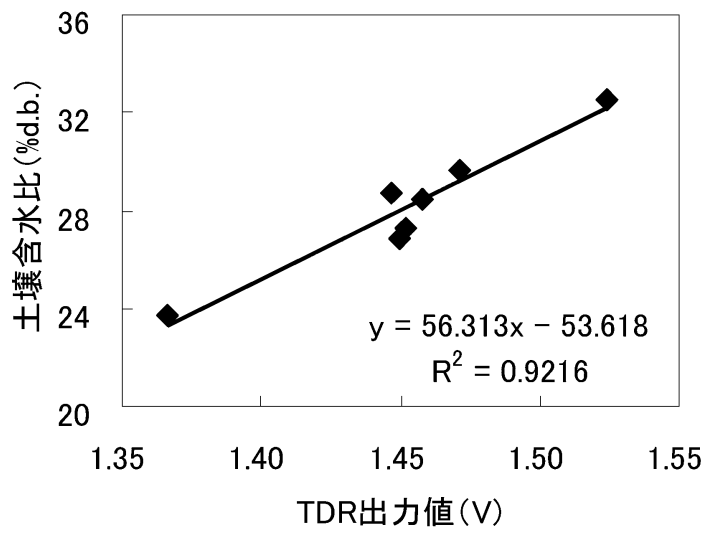

図 3 TDR 水分センサの出力値と土猿含水比 の関係 
き 2 点設置し, 深さ $0 \sim 10 \mathrm{~cm}$ の平均值を求めた. 深さ $10 \sim 50 \mathrm{~cm}$ の土㙥硬度を, 計測前日の降雨量 $32.5 \mathrm{~mm}$, 当日 $4.5 \mathrm{~mm}$ の条件下で, デジタル式貫 入抵抗計 (Agridry 社 : CP40) を用いて $10 \mathrm{~cm}$ 毎 に測定し，併せて同じ深さの体積含水率を挿入式 TDR 水分センサ（深見ら 2006b, 宮本ら 2008) で 測定した。なお，本センサで測定した体積含水率 は, 実測した土壤含水比と体積含水率の関係式 （図 4）に基づいて土壤含水比に換算した。土壌硬 度と土壤水分は 1 区あたり 5 反復測定した。

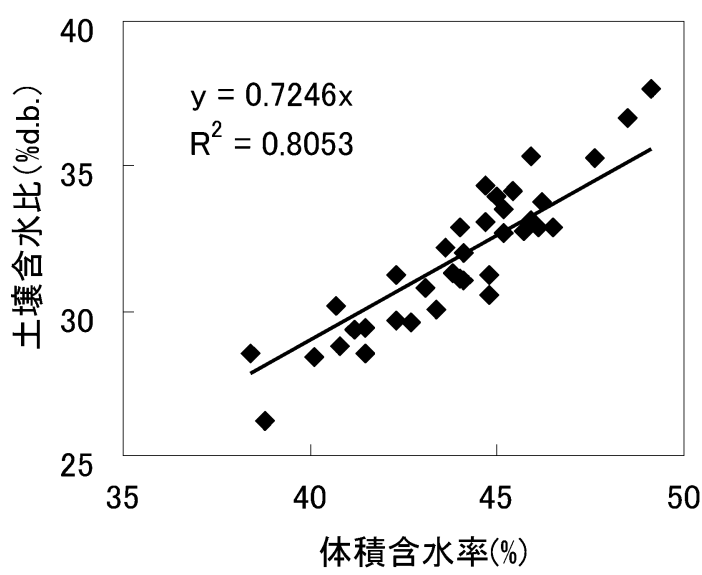

図 4 供試圃場における体積含水率と土壌含水 比の関係
2）作業限界条件の検証

ジャーガル戒場におけるサトゥキビ用機械を対 象に土壌水分と作業性の関係について調査を行っ た. 表 1 に試験条件を示す。対象となる作業機は 心土破砕を行う排土型，耕耘を行うロータリ，植 付を行うプランタおよび収穫を行うハーベスタと した. 調査項目は, 排土型では比抵抗（最大けん 引抵抗/破砕断面積) とすべり率（(無負荷時の進 行距離一負荷時の進行距離)/無負荷時の進行距離 $\times 100)$ ，ロータリでは砕土率（粒径 $2 \mathrm{~cm}$ 以下の 土塊の重量パーセント) と $\mathrm{PTO}$ 動力, プランタ では植付精度 (区画内の植付本数), ハーベス夕で は機体沈下量とトラッシュ率（サトウキビの収穫 物に含まれる枯葉, 土砂などの夾雑物の重量パー セント）とした。排土型のけん引抵抗およびロー タリの PTO 動力は, 所要動力測定システム (深 見ら 2006a）で測定した。排土型の破砕断面積は 作業深 $\times$ 排土板幅 $\times$ ナイフ本数で算出した. すべ り率は, トラク夕後輪を 2 回転させた時の進行距 離を無負荷時, 作業時における後輪 2 回転距離を 負荷時とし算出した。砕土率は, 耕耘後に縦 : 50 $\mathrm{cm} \times$ 横 : $50 \mathrm{~cm} \times$ 深 : 耕耘 (12 cm 程度) の範囲 をサンプリングして篩い分けして求めた，植付精 度は, 植付後に測定区内の苗を掘り出して植付け 本数をカウントして求めた。 ハーベス夕の沈下量 は, 走行後にクローラによって形成された轍深さ を 3 点測定し, 平均值を求めた. トラッシュ率は,

表 1 調査項目の一覧

\begin{tabular}{|c|c|c|c|c|}
\hline 作業名 & $\begin{array}{c}\text { 機械名 } \\
\text { 製造・型式 } \\
{[\text { 製造・トラクタ }}\end{array}$ & $\begin{array}{l}\text { 機械質量 } \\
\text { [5 } \\
\text { 力・質量] }\end{array}$ & 日付・場所 & 調査項目 \\
\hline $\begin{array}{l}\text { 心土 } \\
\text { 破砕 }\end{array}$ & $\begin{array}{c}\text { 排土型 } \\
\text { (プラソイラ }) \\
\text { スガノ・3PY3K } \\
{[\text { ニューホランド・ }} \\
\text { M8160] }\end{array}$ & $\begin{array}{c}290 \mathrm{~kg} \\
\text { (ナイフ } \\
\text { 本数: 2) } \\
{[73.6 \mathrm{~kW} \cdot} \\
5130 \mathrm{~kg}]\end{array}$ & $\begin{array}{c}04 / 11 / 30 \\
\text { 具志頭 } \\
05 / 7 / 28 \text { 首里 } \\
07 / 2 / 8 \text { 与座 }\end{array}$ & $\begin{array}{l}\cdot \text { 比抵抗 } \\
\cdot \text { すべり率 }\end{array}$ \\
\hline 耕耘 & 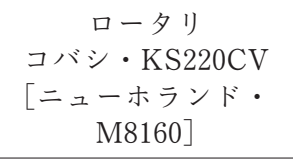 & $\begin{array}{c}660 \mathrm{~kg} \\
{[73.6 \mathrm{~kW} \cdot} \\
5130 \mathrm{~kg}]\end{array}$ & $\begin{array}{c}06 / 9 / 4-5 \\
\text { 場内（糸満） }\end{array}$ & $\begin{array}{l}\text { ·砕土率 } \\
\text { · PTO 動力 }\end{array}$ \\
\hline 植付 & 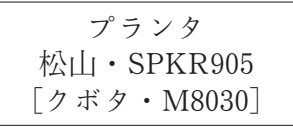 & $\begin{array}{c}560 \mathrm{~kg} \\
{[58.8 \mathrm{~kW} \cdot} \\
3000 \mathrm{~kg}]\end{array}$ & $\begin{array}{c}06 / 9 / 4 \\
\text { 場内 (糸満) }\end{array}$ & • 植付精度 \\
\hline 収穫 & $\begin{array}{c}\text { ハーベスタ } \\
\text { 松元・MCH-15-W-E }\end{array}$ & $\begin{array}{c}4140 \mathrm{~kg} \\
\text { 接地圧 } \\
(35.3 \mathrm{kPa})\end{array}$ & $\begin{array}{c}07 / 8 / 22-23 \\
\text { 場内（糸満） }\end{array}$ & $\begin{array}{l}\text { ・沈下量 } \\
\text { ・トラッシュ率 }\end{array}$ \\
\hline
\end{tabular}


収穫原料を 1 区あたり $15 \mathrm{~kg}$ 程度サンプリング し, 原料茎と夾雑物に選別後, 夾雑物重/全体重 (サンプリング重 $) \times 100$ で算出した.

土壌水分は, 排土型に関しては戒場の場所と実 施日を変えることにより，ロータリ，プランタお よびハーベス夕に関しては圃場潅水量を変えるこ とにより, 各数水準の作業水分条件を得た. 実験 区画は 1 区あたり $10 \mathrm{~m}$ 程度の 3 反復を基準とし た. 作業速度は排土型 : $0.4 \mathrm{~m} / \mathrm{s}$ ，ロータリおよび プランタ: $0.3 \mathrm{~m} / \mathrm{s}$, ハーベスタ : $0.2 \mathrm{~m} / \mathrm{s}$ とした. 土壤含水比は 1 実験につき深さ $0 \sim 10 \mathrm{~cm}$ 範囲を 3 地点サンプリングして平均值を求めた。 土壤硬 度はデジタル式貫入抵抗計 (CP40) を用いて測定 し，排土型で深さ 0 ～ $50 \mathrm{~cm}$, ロータリおよびプラ ンタで $0 \sim 20 \mathrm{~cm}$, ハーベスタで $0 \sim 10 \mathrm{~cm}$ の範囲 に扮いて $1.5 \mathrm{~cm}$ 毎の平均值を求めた。本研究で は, トラク夕作業ではすべり率, 砕土率および植 付精度が, 収穫作業では損失や機体沈下量が大幅 に増大または低下する時点の土畩含水比を作業限 界水分条件と定義して解析を行った。 また, 培土 作業については, 砕土性が作業性に大きく影響す ることから，ロータリ作業の結果を代用できるむ のと仮定した。

\section{3）排水性改善効果の評価}

（1）作業可能日数と増分率

圃場排水性が改善することによって年間あたり の機械作業日数がどの程度拡大するのかを「作業 可能日数率」に基づいて解析した。 ここで，作業 可能日数率とは, 主として機械作業の可能日数を 推定するため, 各地の日降水量 $110 \mathrm{~mm}$ 以上の日 数, 6 時掞よび 14 時々点の快晴, 晴れ, 曇の月別 合計日数等を考慮して月別機械作業可能日数を推 定し，これを各月の日数で割ってパーセントで表 したもの（沖縄県 2000）と定義されている. 本研 究では, 「降雨量が $a \mathrm{~mm}$ 以上の時, 改善区が慣 行区より作業可能日数 $d_{a}$ 日拡大する」と仮定し た場合に打ける閾值 $a(\mathrm{~mm})$ と拡大日数分 $d_{a}$ （日）を人工降雨試験および機械の作業限界条件 に基づいて決定した。さらに，過去 10 年間 (1996 〜2006) の降雨デー夕 (糸数: 気象庁) から, 月毎 に日降雨量むしくは連続降雨量が $a \mathrm{~mm}$ を超え た回数 $n$ (回/月) を抽出し, その 10 年間の平均 值 $N$ (回/月) に $d_{a}$ (日) を乗じて, さらに各月の 日数 $M$ (日) で割ったパーセント值を作業可能日
数の増分率 $I_{a}(\% /$ 月) と定義した. 式(1) に算出法 を示す.

$$
I_{a}=100 d_{a} N / M
$$

したがって, サトゥキビ栽培における各機械の適 期作業期間を $D($ 日), 沖縄県の作業可能日数率を $R(\%)$ とした場合, 慣行区の作業可能日数 $D_{c}$ （日）は $D_{c}=D R$, 改善区の作業可能日数 $D_{a}$ (日) は $D_{a}=D\left(R+I_{a}\right)$ となる.

(2) 作業負担面積

各機械が適期に作業できる作業負担面積 $A$ （ha）は, 各機械の 1 日あたりの圃場作業量 $W$ （ha/日）に作業可能日数 $D_{c}$ (日) むしくは $D_{r}$ (日) を乗じて算出した。 また，サトウキビ栽培におけ る作業名や作業期間等については沖縄県農林水産 部の「平成 18 年さとうきび栽培指針」, 國場作業 量の算出に必要な各機械の作業幅, 作業速度, 圃 場作業効率, 1 日の作業時間㧍よび実作業率等に ついては日本農作業学会の「農作業デー夕集」を 参考にした。

\section{3. 結果および考察}

1）ピット方式の圃場排水効果

人工降雨試験結果を図 5 に示す。ピットからの 排水は降雨量換算で $48 \mathrm{~mm}$ の水が投入されてか ら確認された.さらにその 2 倍 $(96 \mathrm{~mm})$ の潅水を 行うと, 排水開始からの投入量 $(48 \mathrm{~mm})$ の 4 割 に相当する水 $(18 \mathrm{~mm})$ がピット排水されること が, 流量計によりわかった。 この時, 土壌含水比 $(0 \sim 10 \mathrm{~cm})$ は, 慣行区では排水開始時から潅水 停止 5 時間後まで $38 \%$ d.b. 程度で推移するのに

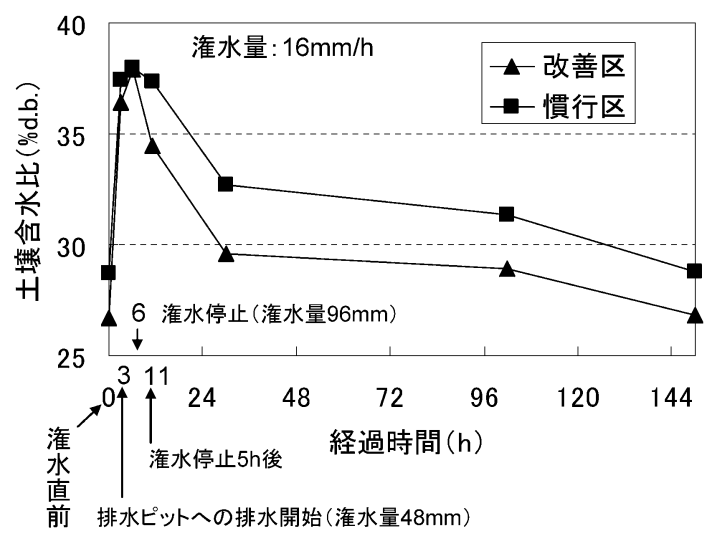

図 5 人工降雨試験に扮ける土壤含水比の比較 
対し，改善区では潅水停止直後から低下し，5 時 間後には $35 \%$ d.b. 程度まで低くなった。また，潅 水直後に $38 \%$ d.b. あった土壌含水比が $30 \%$ d.b. まで低下するのに要する期間は慣行区が 5 日程度 であったのに対し, 改善区では 1 日程度であるこ とから，ピット方式による圑場排水効果が確認で きた。この結果に基づいて, 本研究では「ピット 排水を行う降雨量の時, 改善区が慣行区に比べ作 業可能日数が拡大する」と仮定し, 前述した閾值 $a$ を $50 \mathrm{~mm}$ と定義した.

一方, 深さ $10 \mathrm{~cm}$ 以下の土壤硬度と土壤含水比 は, 改善区は慣行区に比べ, 排水ピットの有孔管 を設置している深さ $30 \mathrm{~cm}$ 付近での土壤含水比

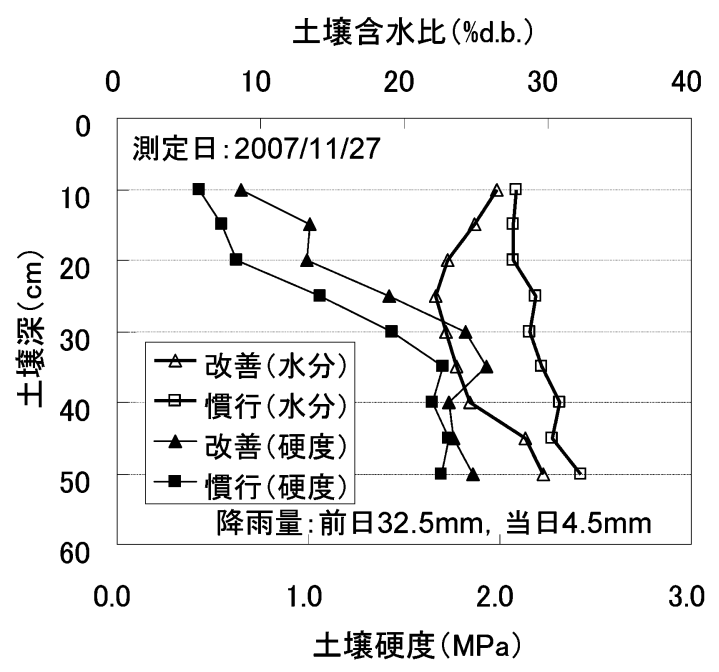

困 6 深さ $10 \mathrm{~cm}$ 以下の土壤物理性の比較
が特に低下し，これに伴い深さ $10 〜 35 \mathrm{~cm}$ にかけ て土壤硬度が高まった（図 6)。つまり，排水ピッ 卜方式では表層だけでなく下層域の排水性改善効 果を有することが確認できた.

\section{2）作業限界水分条件}

機械作業性能と土壌水分の関係の一覧を表 2 に 示す．排土型による心土破砕作業においては，土 褰含水比が $31 \%$ d.b. 程度になると $25 \%$ d.b. 時に 比べ比抵抗が 3 割程度, すべり率が $28 \%$ 程度増 加し, さらに土壤含水比が 34\%d.b. に達するとけ ん引作業自体が不能になった。、ータリによる耕 耘作業では, 土壤含水比が $28 \%$ d.b. 程度になると 25\%d.b. 時に比べ砕土率が $65 \%$ から 40\% 程度に 低下し, 土壤含水比 $34 \%$ d.b. まで増加すると図 7

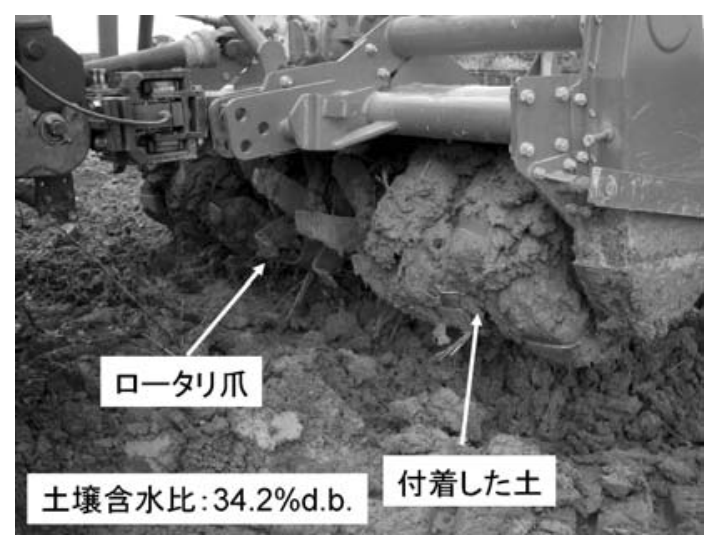

図 7 ロータリ停止時における土の付着状態

表 2 機械作業性能調查結果

\begin{tabular}{|c|c|c|c|}
\hline 機械名 & $\begin{array}{l}\text { 土壤 } \\
\text { 含水比 } \\
(\%)\end{array}$ & $\begin{array}{l}\text { 土壤 } \\
\text { 硬 } \\
\text { (MPa) }\end{array}$ & 調査結果 \\
\hline 排土型 & $\begin{array}{l}25.2 \\
30.5 \\
34.4\end{array}$ & $\begin{array}{l}0.87 \\
0.63 \\
-\end{array}$ & $\begin{array}{c}\text { 比抵抗 : } 36.3 \mathrm{~N} / \mathrm{cm}^{2} \text { すべり率: } 7.5 \% \\
\text { 比抵抗 : } 60.1 \mathrm{~N} / \mathrm{cm}^{2} \text { すべり率 : } 35.6 \% \\
\text { けん引作業不能 }\end{array}$ \\
\hline ロータリ & $\begin{array}{l}24.7 \\
27.8 \\
34.2\end{array}$ & $\begin{array}{l}0.7 \\
0.4 \\
0.4\end{array}$ & $\begin{array}{c}\text { 所要動力: } 70.5 \mathrm{~kW} \text { 砕土率: } 64.9 \% \\
\text { 所要動力: } 70.8 \mathrm{~kW} \text { 砕土率 : } 40.4 \% \\
\text { ロータリ停止 }\end{array}$ \\
\hline プランタ & $\begin{array}{l}25.2 \\
27.6 \\
30.8\end{array}$ & $\begin{array}{l}0.4 \\
0.4 \\
0.3\end{array}$ & 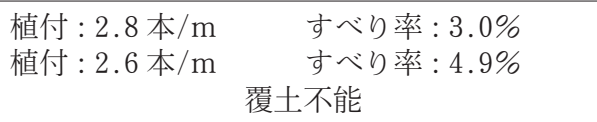 \\
\hline ハーベス夕 & $\begin{array}{l}30.7 \\
33.4 \\
35.5\end{array}$ & $\begin{array}{l}0.3 \\
0.2 \\
0.2\end{array}$ & 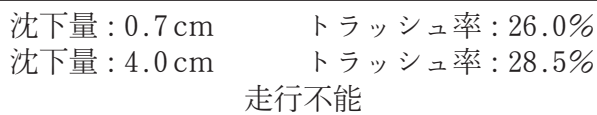 \\
\hline
\end{tabular}


のようにロータリ爪に土が付着し PTO 負荷が増 大してロータリが停止した，プランタによる植付 作業では，土壌含水比 $28 \%$ d.b. 程度までは問題な く作業できたが，30\%d.b. 以上になると苗の覆土 ができず作業不能状態に陥った，以上のことか ら，心土破砕，耕耘抢よび植付作業等では，土袞 含水比が 30\%d.b. 以上になると作業性能が著し く低下屯しくは作業不能となることから，これら の作業に関しては土壌含水比の上限（作業限界水 分条件）を $30 \%$ d.b. と定義した。一方，小型八ー ベスタによる収穫作業では，土壌含水比 $30 \%$ d.b. 程度では走行部の沈下は $1 \mathrm{~cm}$ 未満であったが, $33 \%$ d.b. 程度になると沈下量が $4 \mathrm{~cm}$ 程度に増加 し, さらに $35 \%$ d.b. 以上で走行不能に陥った。 よって, 収穫作業では土畩の圧密が進行する土壌 含水比 $33 \%$ d.b. を土壌水分の上限と定義した.

\section{3）排水技術の評価}

（1）作業可能日数と増分率

図 5 より $50 \mathrm{~mm}$ 以上の降雨後, 改善区では 1 日後に土袞含水比 $30 \%$ d.b. 以下になり, 慣行区で は 2 日後に $33 \%$ d.b. 以下, 5 日後に 30 d.b.\% 以下 になることが推定される。したがって, 心土破砕, 耕耘および植付作業の限界水分条件を 30\% d.b. および収穫作業の限界水分条件を $33 \%$ d.b. と定 義した場合，それぞれの作業期間の拡大日数分 $d_{a}$ は 4 日および 1 日となる. 次に, 過去 10 年間の降 雨デー夕から降雨量が $50 \mathrm{~mm}$ を超える回数 $N$ （回/月）を月毎に抽出し，（1）式より作業可能日
数の増分率 $I_{a}(\% /$ 月) を算出した。表 3 に心土破 砕作業等に打ける月毎の増分率の一覧を示す. 排 水性改善効果によって, 作業可能日数は梅雨前後 の 4 6月で 13〜19\%，台風等によって天気が不 安定になる 9 月で $16 \%$ 増大した。

(2) 作業負担面積

サトウキビ栽培における作型毎の作業名, 作業 期間, 機械名, 1 日の圃場作業量, 作業可能日数抒 よび作業負担面積の一覧を表 4 に示す.ここで, 圃場作業量の算出に必要な各機械の圃場作業効 率，1日の作業時間および実作業率は，それぞれ

表 3 月毎の作業可能日数の増分率

\begin{tabular}{cccccc}
\hline \hline 月 & $\begin{array}{c}N \\
(\text { 回/月) }\end{array}$ & $\begin{array}{c}N \times 4 \\
(\text { 日 })\end{array}$ & $\begin{array}{c}I_{a} \\
(\% / 月)\end{array}$ & $\begin{array}{c}R \\
(\%)\end{array}$ & $\begin{array}{c}R+I_{a} \\
(\%)\end{array}$ \\
\hline 1 & 0.1 & 0 & 1 & 77 & 78 \\
2 & 0.5 & 2 & 6 & 75 & 81 \\
3 & 0.4 & 1 & 5 & 77 & 82 \\
\hline 4 & 1.3 & 5 & 17 & 68 & 85 \\
5 & 1.0 & 4 & 13 & 60 & 73 \\
6 & 1.5 & 6 & 19 & 52 & 71 \\
\hline 7 & 0.7 & 3 & 9 & 74 & 83 \\
8 & 0.6 & 3 & 8 & 65 & 73 \\
9 & 1.2 & 5 & 16 & 73 & 89 \\
\hline 10 & 0.5 & 2 & 6 & 74 & 80 \\
11 & 0.3 & 1 & 4 & 82 & 86 \\
12 & 0.6 & 3 & 8 & 77 & 85 \\
\hline
\end{tabular}

$N$ : 日降雨量むしくは連続降雨量が $50 \mathrm{~mm}$ を超え た回数の 10 年間（1996～2006）の平均值（回）

$I_{a}:$ 作業可能日数の増分率（\%)

$R$ : 沖縄県における作業可能日数率（\%)

表 4 作業可能日数と作業負担面積の一覧

\begin{tabular}{|c|c|c|c|c|c|c|c|c|c|c|}
\hline \multirow{2}{*}{ 作 } & \multirow{2}{*}{ 作業名 } & \multirow{2}{*}{ 適期 } & \multirow{2}{*}{ 機械名 } & \multirow{2}{*}{$\begin{array}{c}1 \text { 日の圃 } \\
\text { 場作業量 } \\
\text { (ha/日) }\end{array}$} & \multicolumn{2}{|c|}{ 作業可能日数 (日) } & \multirow{2}{*}{$\begin{array}{c}\text { 拡大日数 } \\
\text { (日) }\end{array}$} & \multicolumn{2}{|c|}{ 作業負担面積 (ha) } & \multirow{2}{*}{$\begin{array}{c}\text { 拡大面皘 } \\
\text { (ha) }\end{array}$} \\
\hline & & & & & 慣行区 & 改善区 & & 慣行区 & 改善区 & \\
\hline \multirow{6}{*}{$\begin{array}{l}\text { 夏 } \\
\text { 植 }\end{array}$} & 心土破砕 & $7 / 1 \sim 8 / 31$ & トラクタ＋排土型 & 0.73 & 43 & 48 & 5 & 31.6 & 35.6 & 4.0 \\
\hline & 砕土 & $7 / 1 \sim 8 / 31$ & トラクタ＋ロータリ & 0.85 & 43 & 48 & 5 & 36.4 & 41.0 & 4.6 \\
\hline & 植付 & $8 / 1 \sim 9 / 30$ & トラクタ＋プランタ & 0.50 & 42 & 49 & 7 & 20.8 & 24.4 & 3.6 \\
\hline & 平均培土 & $10 / 1 \sim 11 / 30$ & 小型トラクタ＋培土機 & 0.55 & 47 & 50 & 3 & 25.9 & 27.5 & 1.6 \\
\hline & 高培土 & $1 / 1 \sim 3 / 31$ & 小型トラクタ＋培土機 & 0.55 & 68 & 72 & 4 & 37.4 & 39.5 & 2.0 \\
\hline & 収穫 & $12 / 1 \sim 3 / 31$ & 小型ハーベス夕 & 0.37 & 92 & 94 & 2 & 33.8 & 34.3 & 0.6 \\
\hline \multirow{6}{*}{$\begin{array}{l}\text { 春 } \\
\text { 植 }\end{array}$} & 心土破砕 & $1 / 1 \sim 2 / 28$ & トラクタ＋排土型 & 0.73 & 44 & 46 & 2 & 32.3 & 33.9 & 1.6 \\
\hline & 砕土 & $1 / 1 \sim 2 / 28$ & トラクタ+ロータリ & 0.85 & 44 & 46 & 2 & 37.3 & 39.1 & 1.8 \\
\hline & 植付 & $1 / 21 \sim 3 / 31$ & トラクタ+プランタ & 0.50 & 53 & 56 & 3 & 26.3 & 28.0 & 1.7 \\
\hline & 平均培土 & $4 / 1 \sim 5 / 31$ & 小型トラクタ＋培土機 & 0.55 & 39 & 48 & 9 & 21.5 & 26.5 & 5.0 \\
\hline & 高培土 & $5 / 1 \sim 6 / 30$ & 小型トラクタ＋培土機 & 0.55 & 34 & 44 & 10 & 18.7 & 24.1 & 5.4 \\
\hline & 収穫 & $1 / 1 \sim 3 / 31$ & 小型ハーベス夕 & 0.37 & 68 & 69 & 1 & 25.0 & 25.3 & 0.3 \\
\hline \multirow{4}{*}{$\begin{array}{l}\text { 株 } \\
\text { 出 }\end{array}$} & 心土破砕 & $1 / 1 \sim 3 / 31$ & トラクタ＋排土型 & 1.47 & 68 & 72 & 4 & 99.8 & 105.2 & 5.4 \\
\hline & 平均培土 & $4 / 1 \sim 4 / 30$ & 小型トラクタ＋培土機 & 0.55 & 20 & 25 & 5 & 11.0 & 13.8 & 2.8 \\
\hline & 高培土 & $5 / 1 \sim 6 / 30$ & 小型トラクタ＋培土機 & 0.55 & 34 & 44 & 10 & 18.7 & 24.1 & 5.4 \\
\hline & 収穫 & $1 / 1 \sim 3 / 31$ & 小型ハーベス夕 & 0.37 & 68 & 69 & 1 & 25.0 & 25.3 & 0.3 \\
\hline
\end{tabular}


$70 \% ， 8 \mathrm{~h}$ および 70\% とした。同表により，排水 ピット方式を導入すると夏植では 8〜 9月に実施 するプラン夕作業, 春植および株出では 4 6 月 に実施する培土作業の作業可能日数が最も増大 し, 作業負担面積はプランタ作業が 4 ha, 培土作 業が 5 ha 程度増えることが示された。一方，いず れの作型においても収穫作業での作業可能日数の 増加分は僅かであった。

排水性改善効果は，心土破砕をできるだけ乾燥 した土壤状態で実施したほうが，亀裂が入りやす く破砕面積む大きくなるため, 高くなる.したがっ て, 本技術の導入時期は，心土破砕作業が 7, 8 月 になる夏植時が効果的だと言える，また，本技術 をサトウキビ農家法人が所有する固場へ導入し， 作業適期を拡大できれば，法人の受託作業面積の 拡大につながると考えられる。

（3）排水対策コス卜

表 5 にピット造成に要するコストの試算結果を 示す。本技術の施工コストは主に排水ピットの造 成に伴うものであり, その内訳は資材費, 機械 （油圧ショベル）賃借料費および人件費等から構 成され，排水ピット 1 箇所あたりの製造コストは 37,000 円程度である。 また, 排水ピットの更新を 理想的なサトウキビの栽培体系（新植（夏植もし くは春植) 後, 株出 3 回) に抢ける新植時 (4 年に 1 回）に実施した場合，年間コストは 9,000 円程度 に抑えることができる。但し，排水ピットの機能 の持続性や圃場面積当たりに要するピット数等に ついて今後更なる検討が必要である.

\section{5. 摘要}

ジャーガル戋場において排土型心土破砕と明渠

表 5 排水ピット方式のコスト試算

(1ピット当たり )

\begin{tabular}{|c|c|c|c|}
\hline 内訳 & $\begin{array}{c}\text { 単価 } \\
\text { 円 }\end{array}$ & 必要 & $\begin{array}{l}\text { 金額 } \\
\text { 円 }\end{array}$ \\
\hline $\begin{array}{l}\text { 資材費 } \\
\text { 浄水ケーキ } \\
\text { 有孔管 } \Phi 75 \text { mm } \\
\text { 塩ビ管 } \Phi 75 \text { mm }\end{array}$ & $\begin{array}{c}4,000\left(/ \mathrm{m}^{3}\right) \\
350(/ \mathrm{m}) \\
250(/ \mathrm{m})\end{array}$ & $\begin{array}{c}3.38 \mathrm{~m}^{3} \\
10 \mathrm{~m} \\
10 \mathrm{~m}\end{array}$ & $\begin{array}{r}13,520 \\
3,500 \\
2,500\end{array}$ \\
\hline $\begin{array}{l}\text { 機械賃借料等 } \\
\text { 油圧ショベル使用料 } \\
\text { 人件費 }\end{array}$ & $\begin{array}{l}9,000(/ \text { 日) } \\
1,400(/ \mathrm{h})\end{array}$ & $\begin{array}{c}1 \text { 日 } \\
6 \mathrm{~h}\end{array}$ & $\begin{array}{l}9,000 \\
8,400\end{array}$ \\
\hline 合計 & & & 36,920 \\
\hline 4 年 1 回更新時 & & & 9,230 \\
\hline
\end{tabular}

等を組み合わせた簡易な戋場排水性改善技術を開 発し, その効果について検討した。 以下に主な結 果を示す.

1）本排水技術では，春・夏植時には排土型を 格子状, 株出時には条間に沿って施工し, 排水路 付近に排水ピットを造成する.

2）心土破砕抢よび耕耘並びに植付作業等は土 壤含水比が $30 \%$ d.b. 以上になると安定した連続 作業が困難になる。

3）排水ピット方式では, 降雨後速やかに排水 され，降雨量 $100 \mathrm{~mm}$ 程度までの時，慣行区より 4 日早く固場作業が行える.

4）排水ピット方式を導入すると，夏植えでは プランタ作業, 春・株出では培土作業の作業負担 面積が最も増大し，それぞれ 4 ha および 5 ha 程 度作業負担面積が増える。

5）排水ピット作成に要する費用は，1箇所あた り 37,000 円であり, 4 年に 1 回更新した場合, 年 間 9,000 円程度のコストになる。

$$
\text { キーワード }
$$

重粘土, ジャーガル, 心土破砕, 固場排水性, サ トウキビ

\section{引用文献}

深見公一郎・杉本光穂・新里良章 (2006a) : 重粘 土壌に打けるトラク夕作業の所要動力測定シ ステムの開発, 農作業研究, 41 (1) ; 31-36. 深見公一郎・杉本光穂 - 宮本輝仁 - 赤地 徹 - 新 里良章 (2006b)：土壌硬度測定孔を利用した 土壌水分測定技術の開発，テラメカニック ス, $26 ; 61-65$.

深見公一郎 - 杉本光穂 - 赤地 徹 - 新里良章 （2006c）：ジャーガル戒場における心土破砕 と明渠による圈場排水性改善効果, 九州沖縄 農業研究成果情報 $22 ; 81-82$.

泉 裕巳・秋永孝義・國府田佳弘 (1981) : ジャ一 ガル地帯における農業の機械化に関する研究 一ジャーガルの物理的性質一, 琉球大学農学 部学術報告 $28 ; 163-171$.

宮城調勝（1976）：ジャーガル土壌の物理性改良

について, 第 47 回農業土木学会九州支部講 演会シンポジゥム「沖縄の特殊土壌」前刷 ; 41-46.

宮本輝仁・深見公一郎（2008）：土袞硬度之併用 
することにより不飽和土壌中の三次元水分計 測のためのシャフト埋め込み式 TDR プロー ブの試作, 2008 土㙥水分ワークショップ論文 集, 109-114.

沖縄県（2000）: 沖縄県特定高性能農業機械導入 計画 ; 20.

大城喜信・浜川 謙（1980）: よみがえれ土一沖 縄の土壤とその改良一, 新報出版 ; 58-62.

\section{Summary}

To increase the number of days for which an agricultural machine in sugarcane filed of Jahgaru soil, which is heavy clay soil found in Okinawa, we developed a simple field drainage improvement technique that included subsoil breaking and drainage pit creation. Next, we determined the effects of this technique by setting the limit working conditions for the machines; these conditions were derived from field experiments. The limit working condition for sugarcane cultivation, excluding harvesting conditions, was soil water content of $\geqq 30 \%$. When the total rain value was $\geqq 50 \mathrm{~mm}$, the number of days for which a machine could function was 4 days more than that in a conventional setting. On the basis of these results, the area covered by the machine increased by approximately 4 and 5 ha in the planter at summer planting and the hiller at spring and root planting respectively. The cost incurred for creating the drainage pit was approximately 37,000 Yen. However, if the renewal timing considered as once every 4 years, then the cost averages to approximately 9,000 Yen.

\section{Key Words}

heavy clay soil, Jahgaru soil, subsoil breaking, field drainage, sugarcane 